\title{
Distribution patterns and coexistence of six species of the amphipod genus Hyale
}

\author{
D. A. Lancellotti, R. G. Trucco \\ Universidad Católica del Norte, Facultad de Ciencias del Mar, Casilla 117, Coquimbo, Chile
}

\begin{abstract}
The distribution patterns of 6 phytal amphipod species of the genus Hyale that occur on the intertidal rocky shores of Coquimbo, Chile, are described. The species show habitat segregation with respect to the wave-exposure gradient: $H$. maroubrae (small species, $<0.6 \mathrm{~mm}$ cephalon length) and $H$. rubra (large species, $>0.6 \mathrm{~mm}$ cephalon length) occurred in protected environments, whereas $H$ grandicomis, H. hirtipalma and $H$. media (large species) and Hyale sp. (a small species) inhabited exposed environments. With the exception of Hyale sp., all the species were also found in areas with intermediate exposure. However, when they coexist, Hyale spp. show differential occurrence according to microhabitat utilization: in protected environments $H$. rubra was found exclusively on algal patches with high canopies, whereas $H$. maroubrae was abundant on patches with low canopies. In the exposed sectors, the species were found mainly on algal patches with low canopies; they showed pronounced segregation among patches, with Hyale sp. being restricted to turf-forming filamentous algal patches. The association of amphipod occurrence with canopy height and with occasional and seasonal algal patch occurrence in protected environments suggests that the distribution and coexistence of Hyale spp. are controlled by predation and the proximity to the colonization sectors (subtidal). In contrast, the permanent algal patch occurrence in exposed environments suggests that interspecific competition is the main factor influencing the distribution and coexistence patterns of Hyale spp., with lowcanopy algal patches and water movement playing important roles in maintaining the presence of small species with poor competitive ability.
\end{abstract}

\section{INTRODUCTION}

The patterns of coexistence of closely related species living in the intertidal and subtidal shallows differ along environmental gradients, such as salinity (Fenchel 1975, Fenchel \& Kolding 1979, Kolding \& Fenchel 1979, Skadsheim 1983, Cherril \& James 1985. Kroer 1986), wave exposure (Fenchel \& Kolding 1979. Kroer 1986), height in the intertidal (Sameoto 1969, Skadsheim 1984, Buschmann 1990), turbidity (Moore 1973, 1978) and depth in the sediment (Grant 1981. Hill \& Elmgren 1987). As a response to the presence of co-occurring related species, together with speciesspecific physiological, nutritional, morphological and/or behavioural constraints, such segregation is mainly considered to be an effect of interspecific competition. Nevertheless, intra-generic predation (Skadsheim 1984, Dick et al. 1990) and predation by fish (Ayal \& Safriel 1982, Edgar 1983) have also been recognized as factors affecting local distribution and occurrence within the gradient. However, it has been demonstrated that the relative importance of these interactions and of individual species' success is a complex function of the position of the species within the environmental gradient and the local structural complexity of the habitat, thus generating local patterns of distribution and diversity which hinder generalization or the establishment of predictive models.

In Chile, 5 amphipod species of the genus Hyale have been recorded - H. grandicornis (Krøyer), H. hirtipalma (Dana), H. maroubrae Stebbing, H. media (Dana), and H. rubra (Thompson) (E. González 1991) which together with an undescribed sixth species occur in the Coquimbo area, northern Chile, and dominate the phytal communities of the rocky intertidal both in number of species and in abundance (Lancellotti 1990). Despite its importance the genus Hyale has been the subject of few studies (Buschmann \& Santelices 1987, Buschmann 1990) and its ecology and biology are largely unknown. 
This paper is part of an extensive program of research on the reproductive biology and ecology of the Hyale species found in the Coquimbo area. Here, we describe the distribution patterns of the Hyale spp. along the wave-exposure gradient. Specifically, where patterns were present, our purpose was to establish the relative importance of different biological factors along the gradient and to determine to what extent the local complexity of the habitat affects the interspecific interactions

\section{MATERIALS AND METHODS}

Study area. The investigation was carried out in the phytal communities of the rocky intertidal of La Herradura Bay in Coquimbo, and in the northern sector next to its mouth, La Pampilla (Fig. 1). Due to the current system and the absence of significant discharges of fresh water, La Herradura Bay does not have salinity or temperature gradients through the intertidal, with these parameters varying seasonally, at the surface, between 34.10 and $34.70 \%$ and between 14 and $18^{\circ} \mathrm{C}$ respectively (Olivares 1988 ). However,

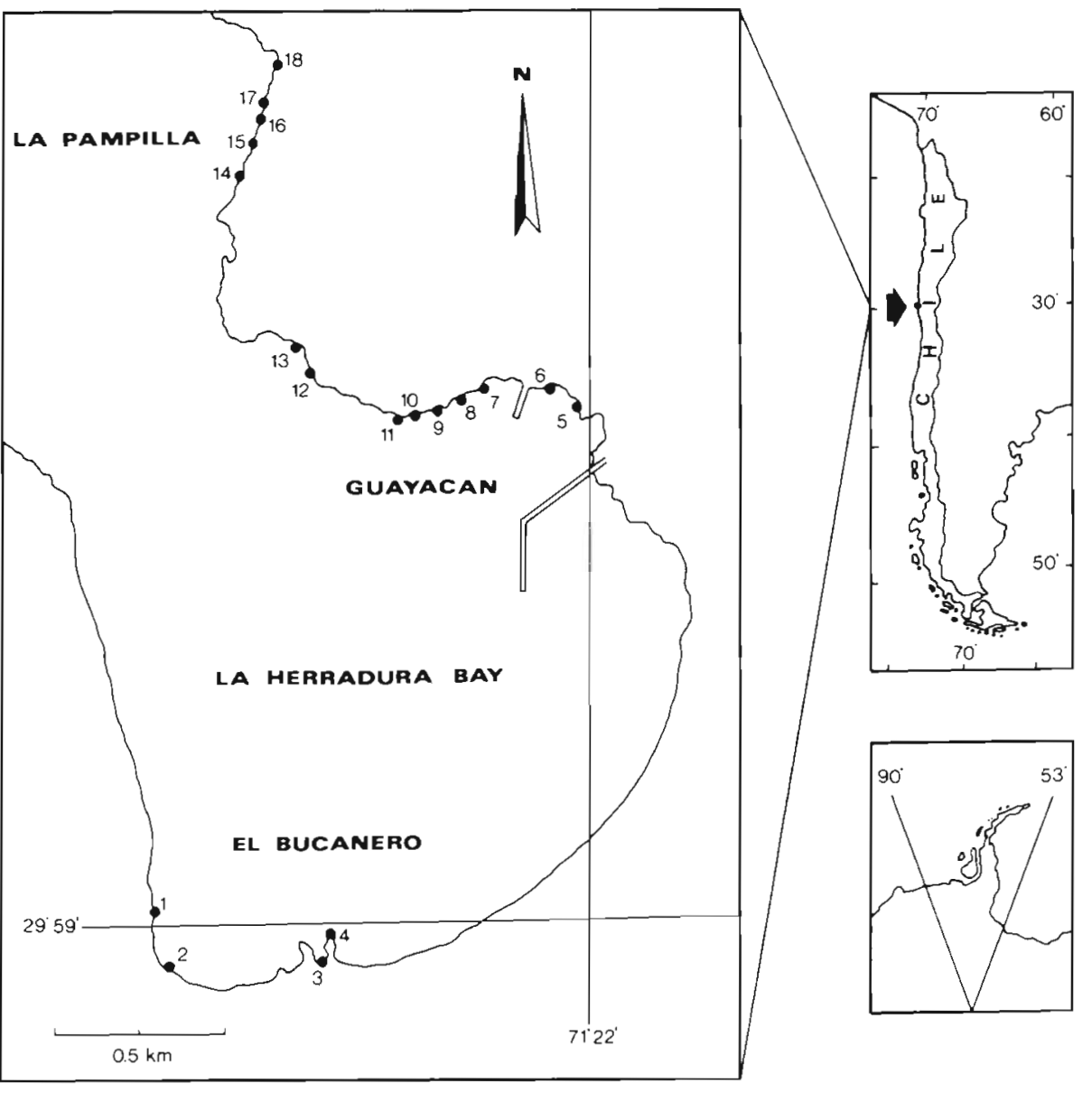

Fig. 1. La Herradura Bay: location of sampling stations the bay has a wide wave-exposure gradient, ranging from protected areas (north and southeast extremes) to areas highly exposed to wave action, e.g. the mouth of the bay and the intertidal of the La Pampilla sector.

Sampling procedure. In April and May 1987 a total of 18 sampling stations were established in the rocky intertidal, which included the whole wave-exposure gradient. These stations were distributed in 3 sectors, 2 of them within the bay - the El Bucanero and Guayacán sectors - and the La Pampilla sector (Fig. 1). At each station, amphipods were sampled during low tide from seaweed patches larger than $1 \mathrm{~m}^{2}$ in areas which had $100 \%$ seaweed coverage.

Three to 7 amphipod samples per patch were obtained by detaching the seaweed from the substrate with a spatula and placing it in a plastic bag containing a $5 \%$ formalin solution. In the laboratory, the amphipods were picked from the seaweed and identified to the species level, and for each species a representative sub-sample of the whole population was classified by sex and measured, using a stereoscopic magnifier with a graduated eyepiece. Only the length of the cephalon was measured, due to the high degree of contraction and bending which is found in the animals after fixation. The seaweeds were identified to species and a thallus sub-sample of each seaweed patch was measured, yielding the average height of the canopy in each patch; this made it possible to establish a relationship between the height of the canopy and the degree of protection offered by the particular patch against predation or environmental harshness, considering that each seaweed patch covered the whole substrate. The seaweeds were dried in a stove for $72 \mathrm{~h}$ at $60^{\circ} \mathrm{C}$ and were weighed to a precision of $0.01 \mathrm{~g}$. In addition, $3 \mathrm{sam}$ ples of amphipods from 0.01 $\mathrm{m}^{2}$ covered by algae were obtained per seaweed patch, which, after being cleaned, dried and weighed, allowed amphipod abundance to be estimated as number of individuals per $0.01 \mathrm{~m}^{2}$. In April 1988, all those patches sampled the 
previous year that still had the desired size and coverage characteristics were sampled again, using the same procedures.

Stations were also visited in July, October and December 1987, and in February and April 1988, to assess the permanence in the intertidal of each seaweed patch sampled in April-May 1987. Following these surveys, the patches of each seaweed species were assigned to one of the following categories: occasional, only one entry (April-May 1987 or April 1988); seasonal, present in 2 or 3 consecutive visits; markedly seasonal, seasonal patch which after disappearing from the intertidal was established again in the same place; and permanent, recorded over the whole period of the study. Additionally, on each occasion the height of the waves impacting the intertidal or present in the area was estimated, allowing the establishment of an arbitrary wave-exposure gradient and the ordering of the sampling stations according to the following scale: I, $<0.1 \mathrm{~m}$ wave height; II, 0.1 to $0.4 \mathrm{~m}$; III, 0.4 to $0.8 \mathrm{~m}$; IV, 0.8 to $1.2 \mathrm{~m} ; \mathrm{V}, 1.2$ to $1.6 \mathrm{~m} ; \mathrm{VI}>1.6 \mathrm{~m}$.

Data processing. An agglomerative, hierarchical classification of data was used for all comparisons between localities and species. Sørensen's quotients of similarity were calculated, and groups were built using a clustering strategy, the unweighted pair-group method with arithmetic averages (UPGMA) (Sneath \& Sokal 1973). Pair associations in the data matrix - stations (columns) and species (rows) - were established by applying 2 procedures: the $R$ technique and the $Q$ technique. The significance of the conglomerates resulting from the $\mathrm{R}$ technique was established following the bootstrap methodology described in Jacksic \& Medel (1987). With the aid of a personal computer, 100 stochastic reassignments were made, independently for each station, of the frequencies observed (rows) [RA3 algorithm defined by Lawlor (1980)]; after reassignment of all the columns, similarity pseudovalues were calculated. The 15300 similarity pseudovalues thus generated were plotted in a frequency histogram, establishing the significance, at a given $\alpha$-level, in the following way: for $\alpha=0.05$, the 95th percentile was calculated by multiplying $15300 \times 0.95$ and the result (14535) was included in the frequency histogram, verifying the similarity level to which it corresponded, i.e. 0.86 . Thus, for any conglomerate, a similarity value $>0.86$ was higher than that expected at random, and was considered significant at the level of $\alpha=0.05$ (Jacksic \& Medel 1987).

For each conglomerate, the Spearman rank correlation coefficient (Zar 1974) was computed for the data on total amphipod numbers per seaweed patch vs the average canopy height of the corresponding patch, separating the species according to the size reached by the adults (see 'Results').
In addition, the statistical significance of each association of pairs in the matrix obtained by the $Q$ technique was compared with the same association resulting from a matrix of similar data, in which the rows (species) were retained but the columns (stations) were replaced by all the patches sampled in the analysis, computing similarity pseudovalues for each association pair using the Jackknife method (modified by Jacksic \& Medel 1987). Thus, the arithmetic mean and the variance were obtained for each association pair of rows, permitting hypotheses to be tested by means of the student's $t$-test (Zar 1974).

The Kolgomorov-Smirnov goodness-of-fit test for grouped ratio scalar data (Zar 1974) was used to test the distribution of the Hyale spp. on the wave-exposure gradient, where the average abundance of amphipods per $0.01 \mathrm{~m}^{2}$ of all the patches, corresponding to an arbitrary scale within the gradient of the respective sector, was used as the observed frequency.

Finally, the diversity of Hyale spp. and of patches of seaweed species by station was computed using the Shannon-Wiener index $\left(H^{\prime}=-\sum \mathrm{p}_{i} \log _{\mathrm{e}} \mathrm{p}_{i}\right.$, where $\mathrm{p}_{i}$ is the proportion of the total counts per station accounted for by species $i$ ), using the Spearman rank correlation coefficient (Zar 1974) to establish the degree of dependence among the indices, by station, or with respect to the wave-exposure gradient.

\section{RESULTS}

\section{Sector characteristics}

One or two seaweed species per station occurred in the protected intertidal of the El Bucanero sector (Table 1). At the most protected stations (Stns 1, 2 and 3 ) more than $50 \%$ of the patches sampled monopolized the substrate and had high canopies, in contrast with the small size and lower canopy height of the patches at the most exposed station (Stn 4) of this sector (Table 1). Concomitant with this pattern, the permanence of the patches varied from occasional (stations with wave-exposure degree I), markedly seasonal (degree II) to permanent (degree III); however, patches at the latter station decreased between July and October, both in coverage (less than $50 \%$ ) and in canopy height (less than $1.0 \mathrm{~cm}$ ).

In the Guayacán sector, the stations were distributed over a wide spectrum of the exposure gradient (Table 1). Across this gradient the stations displayed a pronounced increase in the number of seaweed species and, except for occasional species and Porphyra columbina, the seaweed patches had small canopies. Polysiphonia sp. $1(100 \%$ of the patches at Stn 6 and $50 \%$ of the patches at Stn 5) and Colpomenia sinuosa 
flected in the increase of the diversity of patches by station (Table 1), a highly significant relationship (Spearman rank correlation coefficient, $r=0.813$; $\mathrm{p}<0.001$ ).

\section{Distribution of amphipods}

Hyale rubra and $H$. maroubrae commonly occurred in the El Bucanero sector, both showing a differential distribution along the narrow gradient of this sector (Table 2). However, while $H$. rubra was significantly abundant in the most exposed stations (Stns 3 and 4), H. maroubrae showed a significantly opposite trend. Only one adult specimen each of H. grandicornis and $H$. hirtipalma was found in the sector's most exposed station; the presence of these species was not significant in the area.

The greatest abundance observed during the study was attained by Hyale maroubrae in the Guayacán sector (more than 700 specimens per $0.01 \mathrm{~m}^{2}$ ). As in the El Bucanero sector, H. maroubrae occurred significantly in the most protected stations (degrees I and II), decreasing markedly in abundance until it disap- peared in the degree $\mathrm{V}$ stations (Table 2). H. grandicornis, $H$. hirtipalma and $H$. media occurred significantly in the most exposed stations, with a few representatives of $H$. grandicornis reaching the most protected stations (Table 2 ).

In the La Pampilla sector, all 6 Hyale species were represented; 3 of them, $H$. grandicornis, $H$. hirtipalma and $H$. media, usually occurred at all the stations (Table 2). Hyale sp. was only found at stations with a maximum degree of exposure to waves and in filamentary turf-forming seaweed (Polysiphonia sp. 2 and Centroceras clavulatum), and their pronounced differences in presence among the stations was due to the variation in occurrence of these filamentary turf-forming seaweeds among the stations. These 4 species of Hyale were significantly abundant in the degree VI stations. H. rubra and $H$. maroubrae occurred in seaweed patches at Stn 18 (degree IV), but while H. rubra occurred significantly here, $H$. maroubrae was only represented by 3 adult specimens; both species were found in small patches of Glossophora kunthii and Plocamium cartilagineum occurring in the lower intertidal.

Table 2. Hyale spp. Abundance (mean no. of individuals per $0.01 \mathrm{~m}^{2}, \pm \mathrm{SD}$ ) at the various stations along the wave-exposure gradient in the different sectors. Probabilities shown are for the Kolmogorov-Smirnov test $(D)$. ns: not significant

\begin{tabular}{|c|c|c|c|c|c|c|c|}
\hline Station & Exposure & H. rubra & H. maroubrae & H. grandicornis & H. hirtipalma & H. media & Hyale sp. \\
\hline \multicolumn{8}{|c|}{ El Bucanero } \\
\hline 1 & I & - & $47.0 \pm 0.0$ & - & - & - & - \\
\hline 2 & I & $14.0 \pm 0.0$ & $16.0 \pm 0.0$ & - & - & - & - \\
\hline 3 & II & $51.0 \pm 8.0$ & $3.8 \pm 5.0$ & - & - & - & - \\
\hline \multirow[t]{2}{*}{4} & III & $86.0 \pm 80.2$ & $2.3 \pm 0.6$ & $0.3 \pm 0.6$ & $0.3 \pm 0.6$ & - & - \\
\hline & & $\begin{array}{l}D=0.285 \\
p<0.001\end{array}$ & $\begin{array}{c}D=0.505 \\
p<0.001\end{array}$ & ns & ns & - & - \\
\hline \multicolumn{8}{|c|}{ Guayacán } \\
\hline 5 & III & - & $113.2 \pm 127.4$ & $0.2 \pm 0.5$ & - & - & - \\
\hline 6 & I & - & $590.0 \pm 15.6$ & - & - & - & - \\
\hline 7 & II & - & $575.0 \pm 259.5$ & - & - & - & - \\
\hline 8 & II & - & $188.0 \pm 80.9$ & - & - & - & - \\
\hline 9 & III & - & $153.0 \pm 85.8$ & $0.2 \pm 0.4$ & - & - & - \\
\hline 10 & IV & - & $101.3 \pm 114.0$ & $4.2 \pm 8.5$ & $0.5 \pm 0.6$ & - & - \\
\hline 11 & IV & - & $22.8 \pm 49.2$ & $16.6 \pm 18.0$ & - & $0.2 \pm 0.4$ & - \\
\hline 12 & V & - & $0.3 \pm 0.8$ & $9.0 \pm 13.2$ & $8.8 \pm 9.0$ & $14.5 \pm 31.6$ & - \\
\hline \multirow[t]{2}{*}{13} & V & - & - & $15.2 \pm 33.7$ & $51.8 \pm 90.8$ & $8.8 \pm 11.1$ & - \\
\hline & & - & $\begin{array}{c}D=0.433 \\
p<0.001\end{array}$ & $\begin{array}{c}D=0.586 \\
\mathrm{p}<0.001\end{array}$ & $\begin{array}{c}D=0.793 \\
p<0.001\end{array}$ & $\begin{array}{c}D=0.850 \\
p<0.001\end{array}$ & - \\
\hline \multicolumn{8}{|c|}{ La Pampilla } \\
\hline 14 & VI & - & - & $21.0 \pm 46.4$ & $105.8 \pm 65.9$ & $77.2 \pm 108.2$ & $0.6 \pm 1.3$ \\
\hline 15 & VI & - & - & $110.5 \pm 221.0$ & $34.0 \pm 68.0$ & $75.0 \pm 136.0$ & $54.0 \pm 67.0$ \\
\hline 16 & VI & - & - & $5.5 \pm 10.3$ & $12.5 \pm 18.9$ & $18.5 \pm 21.0$ & $50.0 \pm 99.8$ \\
\hline 17 & VI & - & - & $19.8 \pm 37.3$ & $33.0 \pm 59.2$ & $26.2 \pm 37.8$ & $0.8 \pm 1.3$ \\
\hline \multirow[t]{2}{*}{18} & IV & $23.7 \pm 36.1$ & $0.3 \pm 0.8$ & $3.7 \pm 8.5$ & $2.2 \pm 3.4$ & $7.7 \pm 13.2$ & - \\
\hline & & $\begin{array}{c}D=0.500 \\
p<0.001\end{array}$ & ns & $\begin{array}{l}D=0.431 \\
\mathrm{p}<0.001\end{array}$ & $\begin{array}{c}D=0.454 \\
p<0.001\end{array}$ & $\begin{array}{c}D=0.363 \\
\mathrm{p}<0.001\end{array}$ & $\begin{array}{c}D=0.508 \\
p<0.001\end{array}$ \\
\hline
\end{tabular}




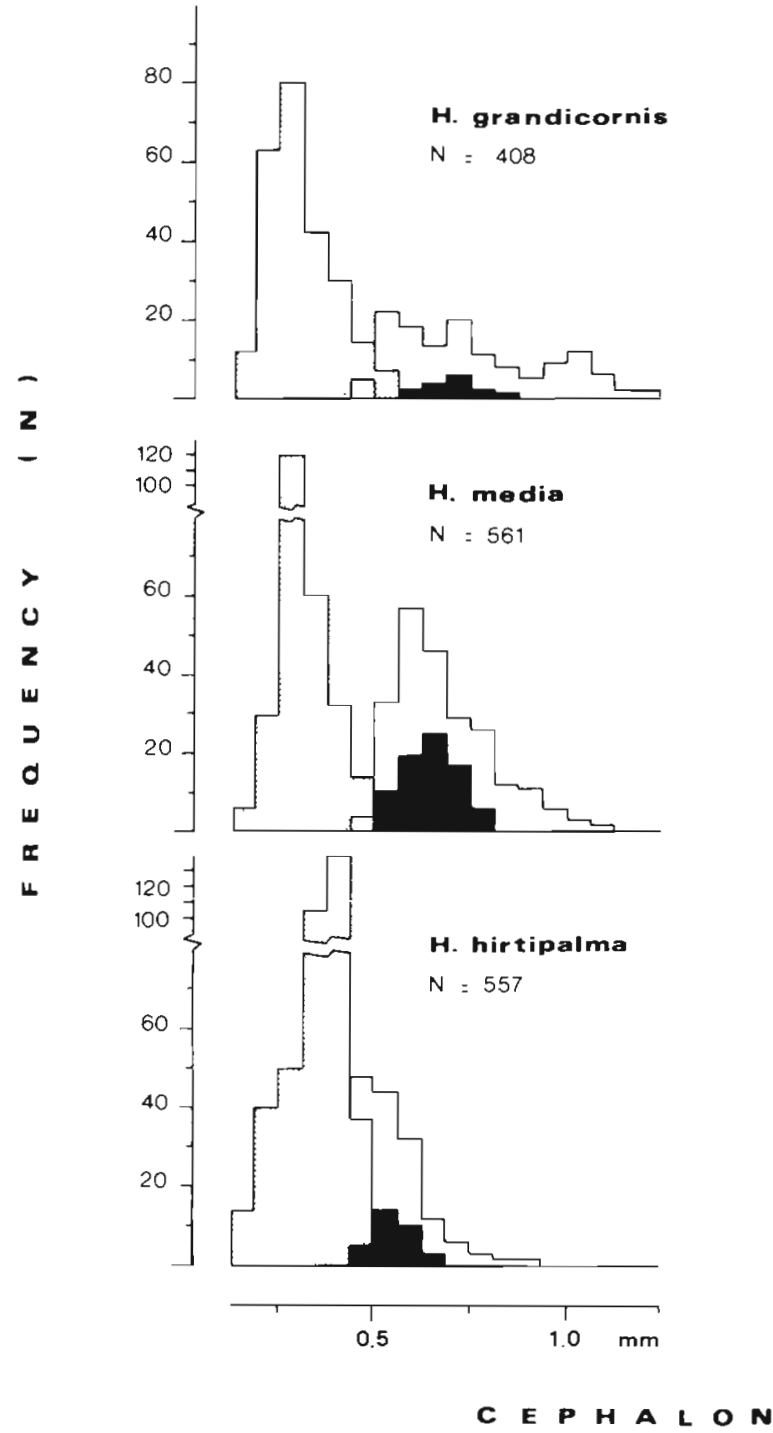

In April-May 1987, the Hyale spp. were reproductively active, and therefore all age groups were represented in the different populations (Fig. 2). The 6 species of the genus could be assigned, according to the size reached by the adult specimens, to 2 categories: (1) large species (cephalon $>0.60 \mathrm{~mm}$ long) - H. grandicornis, $H$. hirtipalma, $H$. media and $H$. rubra; and (2) small species (cephalon $<0.60 \mathrm{~mm}$ long) $-H$. maroubrae and Hyale sp. (Fig. 2).

The conglomerate analysis separated the stations into 3 groups (A, B, C), significant at $\alpha=0.14$ (Fig. 3). The conglomerate groupings arranged the stations according to their degree of exposure. Cluster A included the degree I and II (protected) stations, where Hyale rubra and $H$. maroubrae occurred. Cluster $C$ included the most exposed stations of the gradient (degree $\mathrm{V}$ and VI), where the 4 remaining species were abun-

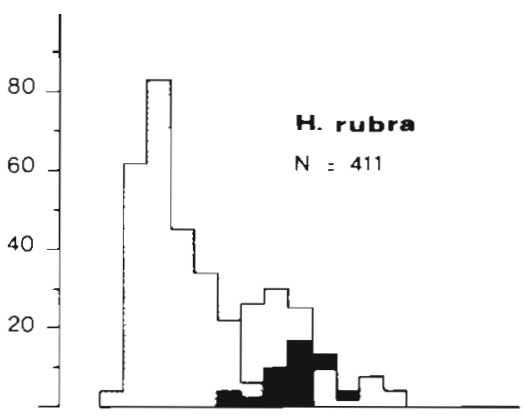

Hyale sp.

$N=215$
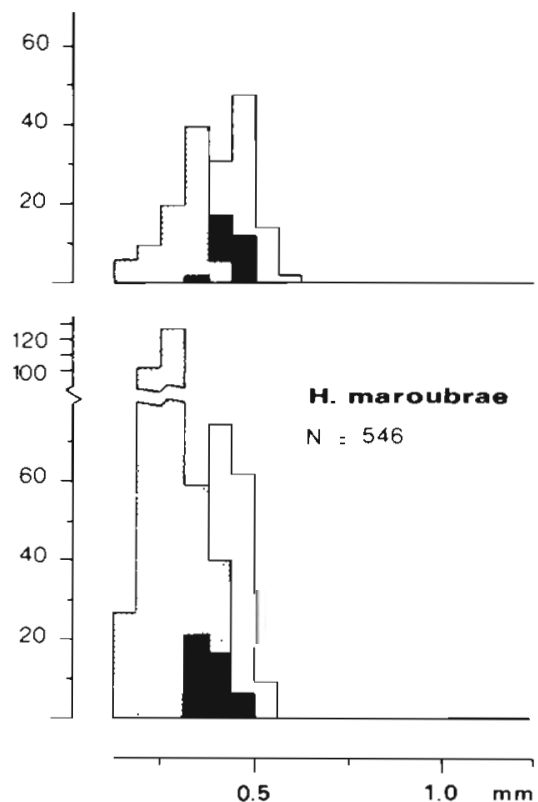

L E N G T H
Fig. 2. Hyale spp. Length-frequency histograms of amphipods from algal patches during April-May 1987 Shaded bars: juveniles; black: ovigerous females; white: males and non-ovigerous females dant, while Cluster B was formed by the stations at the center of the gradient, with the species of both Group A and Group C occurring, except for Hyale sp.

The abundance by patch of the 2 size categories of Hyale spp. showed different responses to canopy height, within the stations of each group of the conglomerate (Table 3). In Cluster $A$, the only 'large' species, H. rubra, was significantly abundant in seaweed patches with high canopies ( $\mathrm{r}=0.7228$; $\mathrm{p}<0.01$ ), while for the 'small' species, H. maroubrae responded significantly to seaweed patches with low canopy height ( $r=-0.6559 ; \mathrm{p}<0.02$ ). In the stations of Cluster $\mathrm{C}$ (Table 3) the abundance of 'large species' (total summed abundance of all species of this category within a patch) showed an inverse relation to the height of the canopy ( $\mathrm{r}=-0.4895 ; \mathrm{p}<0.01$ ); this relationship was not significant for 'small species', even 


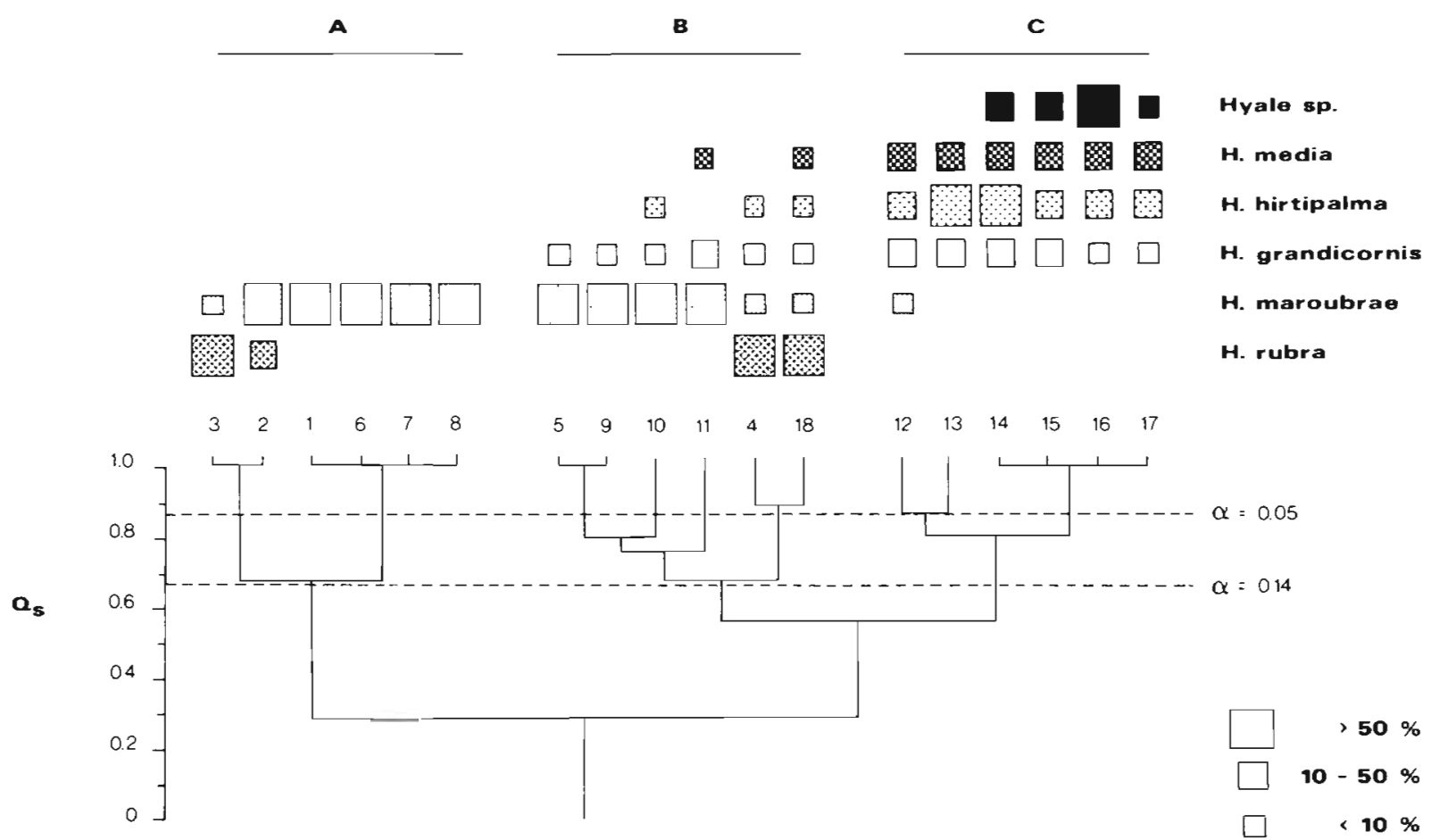

Fig. 3. Hierarchical, agglomerative classification of localities by UPGMA, based on presence/absence data of Hyale spp. (Sørensen index, $Q_{s}$ ). Dashed lines indicate significant levels. Groups A, B and C significant at $\alpha=0.14$. Size of box shows the relative abundance of Hyale spp. at each station

though Hyale sp. (the only representative of this group in exposed sectors) was only abundant in turf-forming seaweeds with a low canopy. In Cluster $B$ and in the overall correlation with Groups A, B and C amalgamated, neither size category showed clear trends with respect to canopy height (Table 3 ).

The analysis of conglomerates derived from the similarity matrix of presence/absence data of Hyale spp. per station (Fig. 4A) and Hyale spp. per patch (Fig. 4B) showed the presence of 2 groups of species directly related to the position within the gradient where they occur ( $H$. grandicornis, $H$. hirtipalma, $H$. media and Hyale sp. vs $H$. rubra and $H$. maroubrae), presenting

Table 3. Hyale spp. Spearman rank correlation coefficient for total no. of amphipods vs canopy height. Large amphipods: $>0.60 \mathrm{~mm}$; small $<0.60 \mathrm{~mm}$. A, B and C represent the corresponding groups in Fig. 3

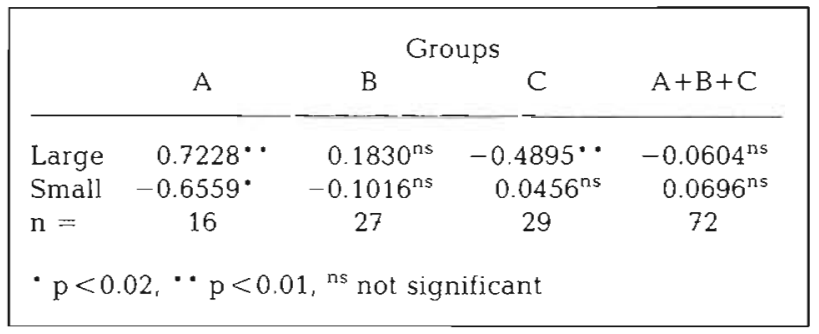

strong differences at the level of similarity at which the species are united in a given cluster (but not in their pair associations), resulting in all the pairs of species in the Hyale spp. matrix per patch (dendrogram of Fig. $4 \mathrm{~B})$ having a level of similarity significantly lower than that of the respective pairs of species of the Hyale spp. matrix per station (Table 4). While this difference for the pair $H$. maroubrae-H. rubra was $21 \%$, for the species of the exposed intertidal the difference was greater: 23 and $29 \%$ for $H$. media-H. hirtipalma and $H$. media-H. grandicornis respectively, and as high as 79 and $88 \%$ for Hyale sp. $-H$. hirtipalma and Hyale sp. $-H$. grandicornis respectively. Together with the existence of a close relation between the diversity of Hyale spp. and the diversity of seaweed patches through the exposure gradient $(r=0.733 ; p<0.001)$, these patterns are related to the greater diversity of more stable habitats in the exposed intertidal, where a greater segregation of Hyale spp. occurs between algal patches.

\section{DISCUSSION}

The 6 phytal amphipod species of the genus Hyale were found to occur differentially along the wave-exposure gradient in the rocky intertidal of La Herradura Bay. $H$. maroubrae and $H$. rubra were found in pro- 


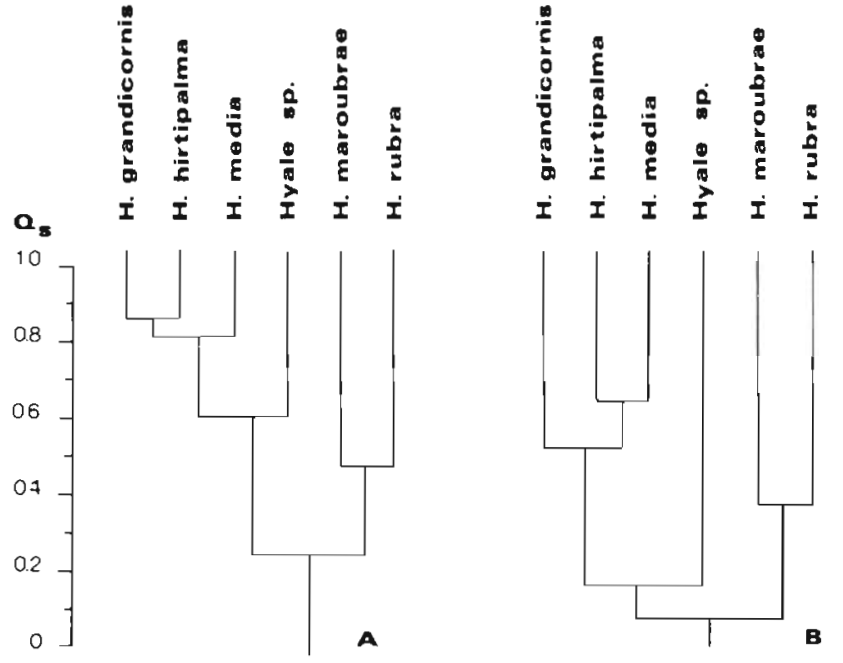

Fig. 4. Hierarchical, agglomerative classification of Hyale spp. by UPGMA, based on presence/absence data (Sørensen index, $\left.Q_{s}\right),(A)$ derived from Hyale spp. matrix per station, and (B) derived from Hyale spp. matrix per patch

tected environments, while $H$. grandicornis, $H$. hirtipalma, $H$. media and Hyale sp. were found to predominate in the exposed intertidal. Together with a consistency in the occurrence of species at stations with similar degrees of exposure, there were pronounced differences in the presence and abundance of $H$. maroubrae and $H$. rubra in the protected sectors, associated with the canopy height of the seaweed patches present. These species showed inverse patterns, with $H$. rubra (large species) occurring at stations containing seaweed patches with high canopies, H. maroubrae (small species) at stations containing patches with low canopies. The occurrence of large-sized amphi- pods in patches with dense canopy has generally been considered to be the result of pressure from predators (mainly fish) (Vince et al. 1976, Stoner 1982, Edgar 1983, Orth et al. 1984), which are responsible for their selective elimination in less structured seaweed patches and/or in those with low canopies; in smaller seaweeds only juveniles or small species of amphipods which escape the high predation pressure occur (Nelson 1979a, b, Crowder \& Cooper 1982, Edgar 1983, Russo 1987). As foraging behaviour is a complex function of the habitat characteristics of predator and prey, predation is favored in benign environments (protected from wave action) (reviewed by Undewood \& Denley 1984), where predators have higher efficiency and perseverance in the attack. Research work carried out by Núñez \& Vásquez (1987) in fish communities associated with a kelp bed of Lessonia traveculata in La Herradura Bay demonstrated that one of the main dietary components of the fish Cheilodactylus variegatus was amphipods that occurred in turf-forming seaweed within the kelp. School juveniles of C. variegatus frequently forage in the protected intertidal of the Guayacán sector during high tide, feeding actively on patches of Polysiphonia sp. 1 where, together with $H$. maroubrae, 2 other species of small amphipods (Aora sp. and Elasmopus sp.) abound (Lancellotti \& Trucco pers. obs.). Despite a lack of information on the preferred size of prey, the constant presence of fish in this protected sector suggests the selective removal of large amphipods

The presence of a high, dense canopy in the El Bucanero sector allows us to predict the occurrence of larger amphipod species but not their identity or diversity. The invertebrate composition associated with a plant, together with predation intensity and the nature

Table 4. Serensen similarity index values (lower left-hand part of table) for the matrix of Hyale spp. per station ( $\mathrm{n}=18$ ) (upper value), and of Hyale spp. per patch ( $\mathrm{n}=73$ ) (lower value). Upper right-hand part of table shows calculated $t$-values; '+++' indicates $\mathrm{p}<0.001$

\begin{tabular}{|c|c|c|c|c|c|c|}
\hline Species & H. grandiconis & H. hirtipalma & H. maroubrae & H. media & H. rubra & Hyale sp \\
\hline H. grandicornis & & $\begin{array}{c}114.10 \\
+++\end{array}$ & $\begin{array}{c}117.83 \\
+++\end{array}$ & $\begin{array}{l}61.71 \\
+++\end{array}$ & $\begin{array}{l}30.12 \\
+++\end{array}$ & $\begin{array}{l}86.72 \\
+++\end{array}$ \\
\hline H. hirtipalma & $\begin{array}{l}0.86 \\
0.46\end{array}$ & & $\begin{array}{l}50.54 \\
+++\end{array}$ & $\begin{array}{l}51.18 \\
+++\end{array}$ & $\begin{array}{l}34.04 \\
+++\end{array}$ & $\begin{array}{l}86.17 \\
+++\end{array}$ \\
\hline H. maroubrae & $\begin{array}{l}0.56 \\
0.10\end{array}$ & $\begin{array}{l}0.36 \\
0.14\end{array}$ & & $\begin{array}{l}62.15 \\
+++\end{array}$ & $\begin{array}{l}18.04 \\
+++\end{array}$ & - \\
\hline H. media & $\begin{array}{l}0.80 \\
0.57\end{array}$ & $\begin{array}{l}0.82 \\
0.63\end{array}$ & $\begin{array}{l}0.28 \\
0.03\end{array}$ & & $\begin{array}{l}23.29 \\
+++\end{array}$ & $\begin{array}{l}65.52 \\
+++\end{array}$ \\
\hline H. rubra & $\begin{array}{l}0.25 \\
0.10\end{array}$ & $\begin{array}{l}0.31 \\
0.11\end{array}$ & $\begin{array}{l}0.47 \\
0.37\end{array}$ & $\begin{array}{l}0.17 \\
0.05\end{array}$ & & - \\
\hline Hyale sp. & $\begin{array}{l}0.50 \\
0.06\end{array}$ & $\begin{array}{l}0.61 \\
0.13\end{array}$ & $\begin{array}{l}0.0 \\
0.0\end{array}$ & $\begin{array}{l}0.66 \\
0.29\end{array}$ & $\begin{array}{l}0.0 \\
0.0\end{array}$ & \\
\hline
\end{tabular}


of the species, is highly dependent, among other factors, on the permanence of the habitat-plant and of the size of the patch (Addicott et al. 1987). The importance of the density-dependent biotic interactions generally increases with the permanence of the habitat (Southwood 1977, 1988, Pickett \& White 1985). In the protected sectors of the bay, in contrast to those in exposed areas, the permanence of the seaweed patches is highly variable over time, with amphipod abundance having a direct relationship with the permanence of the patch in the intertidal (Lancellotti 1990). Therefore, the occasional or seasonal occurrence of patches in the El Bucanero sector would facilitate the presence of fast-colonizing species and/or those where the source of colonizers is closest (Hargeby 1990). Of the 6 amphipod species studied, Hyale rubra is the only species that occurs in the subtidal, abounding in seagrass meadows of Heterozostera tasmanica (S. A. González 1991) and in the subtidal patches of Ulva rigida and Gigartina chamissoi in La Herradura Bay (Lancellotti \& Trucco unpubl. data). The ability to colonize the intertidal through the subtidal appears to be an important factor in facilitating the existence and dominance of $H$. rubra in the El Bucanero sector, this being a comparative advantage over congeners that live in the exposed intertidal and the protected sector of Guayacán. Thus, in December 1988, in a dense patch of $U$. rigida that had remained for 5 mo in the intertidal of Stn 3, H. media was present and adult $H$. grandicornis and $H$. hirtipalma reached abundances 7 to 10 times greater than those observed for these species in April-May 1987. Nevertheless, although abundant, $H$. rubra did not exceed 100 amphipods per 0.01 $\mathrm{m}^{2}$ and $H$. maroubrae was not found, suggesting that inter-specific interactions may already have been occurring.

The larger body size reached by 3 out of the 4 species that occur in the most exposed stations (degrees $\mathrm{V}$ and VI), the inverse relationship of their abundances to canopy height and the conditions of intense wave action suggest that predation is unlikely to be responsible for the observed pattern of amphipod occurrence in the exposed intertidal. If predation is of little importance, then the relative importance of inter-specific competition in structuring the communities would be expected to be the primary factor (Menge \& Sutherland 1987). Thus, the great variety of seaweed species, the permanent presence of these patches in the intertidal and the differential occurrence of Hyale spp. suggest that competitive interactions may be responsible for the distribution of Hyale spp. in the sectors heavily exposed to waves.

In the heavily exposed rocky intertidal, seaweed patches with large canopies provide a slightly adhesive surface for amphipods (Wakabara et al. 1983,
Buschmann 1990), which, coupled with the inefficiency of predators in these environments (Underwood \& Denley 1984), causes turf-forming seaweed with low canopies to be inhabited mainly by the genus Hyale. The differential occurrence of Hyale spp. among seaweed patches seems to be a common pattern in the exposed intertidal (Buschmann 1990, Lancellotti 1990), and is likely due to the greater variety of microhabitat present (Fendwick 1976). The occurrence of amphipods on patches of different seaweed species can be controlled by active selection and by patch-specific differential survival (Virnstein \& Howard 1987), resulting from the compromise between shelter and food (Buschmann 1990) or from a differential efficiency of feeding mechanisms (Lancellotti 1990), displacing smaller and/or competitively inferior species.

The 6 species display morphological characteristics of amphipods adapted to areas with strong waves; strong gnathopods and body, and strong, serrated pereiopods (Moore 1973, Wakabara et al. 1983, Hirayama \& Kikuchi 1990).

Within the range of microhabitats, in exposed areas where water flows quickly over filamentary turf-forming seaweeds (Polysiphonia sp. 2 and Centroceras clavulatum), large-sized amphipods did not occur, whereas Hyale sp. was abundant and significant numbers of juvenile Hyale media were present. This suggests the existence of a threshold size for success in the survival of amphipods on seaweed patches, permitting the occurrence of small individuals and small species that possibly are competitively inferior [similar patterns have been demonstrated for amphipods by Fenchel \& Kolding (1979) and Skadsheim (1984)]. Consequently, the absence of $H$. rubra and $H$. maroubrae at degree VI stations, despite the presence of both (mainly H. rubra) at Stn 18 (degree IV), would be due to these species' inferior competitive abilities. In general, the patterns of coexistence observed in Hyale spp. along the exposure gradient coincide with the prediction by the general model of an increase in the specialization of amphipods (in utilization of seaweed habitat) as the number of co-existing congeners increases (Edgar 1983), in which competitive interspecific interactions are considered important. Other phytal species were too uncommon to account for significant competition and predation. In spite of the fact that the factors influencing differential mortality of species could be operating other than inferred here, our results suggest that complex interactions among predators, seaweed permanence, proximity of a source of colonizers in sheltered areas, and microhabitat diversity and competition in the exposed intertidal are principally responsible for the pattern of distribution observed in Hyale spp. along the wave-exposure gradient of the rocky intertidal of La Herradura Bay. 
Acknowledgements. The authors thank 3 anonymous referees for their very helpful comments and corrections to the English.

\section{LITERATURE CITED}

Addicott, J. F., Aho, J. M., Antolin, M. F., Padilla, D. K., Richardson, J. S., Soluk, D. A. (1987). Ecological neighborhoods: scaling environmental patterns. Oikos 49: 340-346

Ayal, Y., Safriel, U. N. (1982). Role of competition and predation in determining habitat occupancy of Cerithiidae (Gastropoda: Prosobranchia) on the rocky intertidal, Red Sea coasts of Sinai. Mar. Biol. 70: 305-316

Buschmann, A. H. (1990). Intertidal macroalgae as refuge and food for Amphipoda in central Chile. Aquat. Bot. 36: $237-245$

Buschmann, A. H., Santelices, B. (1987). Micrograzers and spore release in Iridaea laminarioides Bory (Rhodophyta: Gigartinales). J. exp. mar. Biol. Ecol. 108: 171-179

Cherrill, A. J., James, R. (1985). The distribution and habitat preferences of four species of Hydrobiidae in East Anglia. J. Conch. 32: 123-133

Crowder, L. B., Cooper, W. E. (1982). Habitat structural complexity and the interaction between bluegills and their prey. Ecology 63(6): 1802-1813

Dick, J. T. A., Irvine, D. E., Elwood, R. W. (1990). Differential predations by males on moulted females may explain the competitive displacement of Gammarus duebeni by $G$. pulex (Amphipoda). Behav. Ecol. Sociobiol. 26: 41-45

Edgar, G. J. (1983). The ecology of south-east Tasmanian phytal animal communities. IV. Factors affecting the distribution of ampithoid amphipods among algae. J. exp. mar. Biol. Ecol. 70: 205-225

Fenchel, T (1975). Factors determining the distribution patterns of mud snails (Hydrobiidae). Oecologia 20: 1-17

Fenchel, T., Kolding, S. (1979). Habitat selection and distribution patterns of five species of the amphipod genus Gammarus. Oikos 33: 316-322

Fendwick, G. D. (1976). The effect of wave exposure on the amphipod faúna of the alga Caulerpa brownii. J. exp. mar. Biol. Ecol. 25: 1-18

González, E. (1991). Actual state of gammaridean amphipoda taxonomy and catalogue of species from Chile. Hydrobiologia 223: 47-68

González, S. A. (1991). Heterozostera tasmanica (Martens ex Aschers) Den Hartog y comunidad asociada en el norte de Chile. Tésis, Universidad Católica del Norte, Coquimbo

Grant, J. (1981). Factors affecting the occurrence of intertidal amphipods in reducing sediments. J, exp. mar. Biol. Ecol. 49: $203-216$

Hargeby, A. (1990). Macrophyte associated invertebrates and the effect of habitat permanence. Oikos 57: 338-346

Hill, C., Elmgren, R. (1987). Vertical distribution in the sediment in the co-occurring benthic amphipods Pontoporeia affinis and $P$. femorata. Oikos 49: 221-229

Hirayama, A., Kikuchi, T (1980). Caprellid fauna associated with subtidal algal beds along the coast of the Oshika peninsula, Tohoku district. Publ. Amakusa mar. biol. Lab. 5: $171-188$

Jacksic, F., Medel, R. (1987). El acuchillamiento de datos como método de obtención de intervalos de confianza y de prueba de hipótesis para índices ecológicos. Medio ambiente 8: $95-103$

Kolding, S., Fenchel, T (1979). Coexistence and life cycle characteristics of five species of the amphipod genus Gammarus. Oikos 33: 323-327
Kroer, N. (1986). Distribution and habitat segregation of four species of Idotea (Isopoda) in a Danish fjord. Ophelia 25 199-207

Lancellotti, D. A. (1990). Morfología funcional de alimentación y su relación con la utilización del hábitat en Hyale spp. Tésis, Universidad Católica del Norte, Coquimbo

Lawlor, L. R. (1980). Structure and stability in natural and randomly constructed competitive communities. Am. Nat. 116: $394-408$

Menge, B. A., Sutherland, J. P. (1987). Community regulation variation in disturbance, competition and predation in relation to environmental stress and recruitment. Am. Nat. 130: $730-757$

Moore, P. G. (1973). The kelp fauna of northeast Britain. II Multivariate classification: turbidity as an ecological factor. J. exp. mar. Biol. Ecol 13: 127-163

Moore, P. G. (1978). Turbidity and kelp holdfast amphipoda I. Wales and S.W. England. J. exp. Mar. Biol. Ecol. 32: $53-96$

Nelson, W. G. (1979a). An analysis of stuctural pattern in an eelgrass (Zostera marina L.) amphipod community. J. exp. mar. Biol. Ecol. 39: 231-264

Nelson, W. G. (1979b). Experimental studies of selective predation on amphipods: consequences for amphipod distribution and abundance. J. exp. mar. Biol. Ecol. 38: 225-245

Núnez, L., Vásquez, J. A. (1987). Observaciones tróficas y de distribución espacial de peces asociados a un bosque submareal de Lessonia trabeculata. Estud. Oceanol. 6: 79-85

Olivares, J. (1988). Variación temporal de las condiciones oceanográficas en Bahía Herradura de Guayacán (Chile). Biota 4: 89-106

Orth, R. J., Heck, K. L., van Montfrans, J. (1984). Faunal communities in seagrass beds: a review of the influence of plant structure and prey characteristics on predator-prey relationships. Estuaries 7: 339-350

Pickett, S. T. A., White, P. W. (1985). The ecology of natural disturbance and patch dynamics. Academic Press, New York

Russo, A. R. (1987). Role of habitat complexity in mediating predation by the gray damselfish Abudefduf sordidus on epiphytal amphipods. Mar. Ecol. Prog. Ser. 36: 101-105

Sameoto, D. D. (1969), Comparative ecology, life histories, and behavior of intertidal sand-burrowing amphipods (Crustacea: Haustoriidae) at Cape Cod. J. Fish. Res. Bd Can. 26: 361-388

Skadsheim, A. (1983). The ecology of intertidal amphipods in the Oslofjord. Distributions and responses to physical factors. Crustaceana 44:225-244

Skadsheim, A. (1984). Coexistence and reproductive adaptations of amphipods: the role of environmental heterogeneity. Oikos 43: 94-103

Sneath, P. H. A., Sokal, R. R. (1973). Numerical taxonomy. W. H. Freeman and Company, San Francisco

Southwood, T. R. E. (1977). Habitat, the templet for ecological strategies? J. Anim. Ecol. 46: 337-365

Southwood, T R. E. (1988). Tactics, strategies and templets. Oikos 52: 3-18

Stoner, A. W. (1982). The influence of benthic macrophytes on the foraging behaviour of pinfish, Lagodon rhomboides (Linnaeus). J. exp. mar. Biol. Ecol. 58: 271-284

Underwood, A. J., Denley, E. J. (1984). Paradigms, explanations and generalizations in models for the structure of intertidal communities on rocky shores. In: Strong, D. R., Simberloff, D., Abele, L. G., Thistle, A. B. (eds.) Ecological communities: conceptual issues and the evidence. Princeton University Press, Princeton, p. 151-180 
Vince, S., Valiela, I., Backus, N., Teal, J. M. (1976). Predation by the salt marsh killifish Fundulus heteroclitus (L.) in relation to prey size and habitat structure: consequences for prey distribution and abundance. J exp. mar Biol. Ecol. 23: $255-266$

Virnstein, R. W., Howard, R. K. (1987). Motile fauna of marine macrophytes in the Indian River lagoon, Florida. I.

This article was presented by J. E. Winter, Valdivia, Chile
Comparisons among three species of seagrasses from adjacent beds. Bull. mar. Sci. 41:1-12

Wakabara, Y., Tararam, A. S., Takeda, A. M. (1983) Comparative study of the amphipod fauna on Sargassum of the Itanhaém shores, Brazil. J. crust. Biol. 3: 602-607

Zar, J. (1974). Biostatistical analysis. Prentice-Hall, Englewood Cliffs, NJ

Manuscript first received: July 30, 1991

Revised version accepted: December 9, 1992 